\title{
COMPLEMENTATION AT THE ARG-7 LOCUS IN CHLAMYDOMONAS REINHARDI
}

\author{
R. LOPPES* and R. MATAGNE \\ Laboratory of Genetics, University of Liège, B-4000 Liège, Belgium \\ and \\ P. J. STRIJKERT
}

Philips Research Laboratories, N. V. Philips' Gloeilampenfabrieken, Eindhoven, The Netherlands

Received 10.viii.71

\section{INTRODUGTION}

Althougr the green alga Chlamydomonas reinhardi may now be considered as a classical material in both genetical and biochemical research, very little work has been devoted to the study of genetic complementation. This failure may be explained by the fact that in this alga the diploid state is normally restricted to the zygote which, under the proper conditions, immediately undergoes meiosis.

In 1967, however, Ebersold demonstrated that immature zygotes of Chlamydomonas reinhardi could occasionally divide mitotically to give rise to stable diploid vegetative cells. By crossing different auxotrophs in various combinations, this author succeeded in selecting on minimal medium several diploid strains, each of them heterozygous for two mutant genes. That these strains were really diploids carrying both mutations was supported by strong cytological and genetical arguments.

This method has been applied to test whether complementation occurred between closely linked flagellar mutants (paralysed flagella $p f$ 18): no interallelic complementation was found in that system (Starling, 1969). In the course of our experiments on the isolation and characterisation of argininerequiring mutants of Chlamydomonas reinhardi, we found that among the 15 newly isolated mutants, seven were lacking the same enzyme argininosuccinate lyase like the arg-7 mutant previously isolated by Gillham (1965). This enzyme catalyses the splitting of argininosuccinate to arginine and fumarate and seems to play a key role in the regulation of arginine metabolism in Chlamydomonas (Strijkert and Sussenbach, 1969). Argininosuccinate lyase has been purified from beef liver: it was shown to have a molecular weight of 202,000 and to be formed of at least two subunits (Havir et al., 1965).

This paper deals with the study of the gene controlling the formation of argininosuccinate lyase. Allelic complementation was shown to occur between certain pairs of mutants lacking this enzyme. Convincing evidence for diploidy has been gained from cytological, genetical and biochemical studies. The properties of the enzyme present in stable diploids displaying complementation were investigated in comparison with the properties of the wild-type enzyme.

This work constitutes, to our knowledge, the first attempt at analysing in Chlamydomonas the fine structure of a gene in relation to the enzymatic properties of the protein controlled by this gene.

* Chercheur qualifié du Fonds National Belge de la Recherche Scientifique.

Q 2 


\section{Materials AND MEthods}

Strains

The wild-type strain $137 C$ and the mutant strains $\arg -1$ and $\arg -7$ were obtained from R. P. Levine (Harvard University).

Arg-1: linkage group I, grows on ornithine, citrulline and arginine (Ebersold, 1956), lacks acetylglutamylphosphate reductase (Strijkert and Sussenbach, 1969).

Arg-7: linkage group I, six units apart from arg-1, grows only on arginine (Gillham, 1965), lacks argininosuccinate lyase (Strijkert, unpublished).

New arg-7 mutants: arg-7-1, arg-7-2, arg-7-3, arg-7-4 were isolated after treatment with ethyl methanesulfonate, arg-7-5 after treatment with ultraviolet light (Loppes, 1969, 1970). All these mutants grow only on arginine and do not display any argininosuccinate lyase activity (Strijkert and Loppes, unpublished). The general procedures for selecting these mutants have been described elsewhere (Loppes, 1969).

\section{Media}

The media used in these experiments and their abbreviations are as follows: $\mathrm{M}(=400 \mathrm{~N})=$ basal minimal medium containing $400 \mathrm{mg} / \mathrm{l}$. $\mathrm{NH}_{4} \mathrm{Cl}$ (Loppes, 1966); $40 \mathrm{~N}$ and $20 \mathrm{~N}=$ media containing respectively 40 and $20 \mathrm{mg} . / 1$. $\mathrm{NH}_{4} \mathrm{Cl}$. They may be supplemented with arginine: $20 \mathrm{~N}+50 \mathrm{arg}$, for example, is a medium containing $20 \mathrm{mg} . / 1 . \mathrm{NH}_{4} \mathrm{Cl}$ and $50 \mathrm{mg}$./1. arginine. $\mathrm{M}-\mathrm{N}+\mathrm{YE}=\mathrm{M}$ medium deprived of $\mathrm{NH}_{4} \mathrm{Cl}$ and supplemented with $4 \mathrm{~g}$./1. Difco yeast extract.

\section{Genetical analysis}

During the course of this work, all strains were routinely maintained on $\mathrm{M}-\mathrm{N}+\mathrm{YE}$ medium: some of the mutants indeed were $\mathrm{NH}_{4}$-sensitive (Loppes, 1969) and unable to grow on the usual complete medium.

Crosses, maturation of zygotes and genetical analysis were carried out according to the methods of Levine and Ebersold (1958).

Zygote plating analysis: mature zygotes were plated on $\mathrm{M}-\mathrm{N}+20$ arg medium. After 5 days, colonies issuing from the zygotes were replica-plated on to $\mathrm{M}$ and $\mathrm{M}-\mathrm{N}+20 \mathrm{arg}$ media. The percentage of $W T$ recombinants was calculated from the number of colonies growing on both media.

Random spore plating analysis : after germination of the zygotes on $M-N$ +20 arg medium, the spores were collected at random and plated on $M$

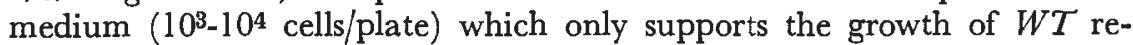
combinants. The number of viable spores was determined by plating diluted samples on $\mathrm{M}-\mathrm{N}+20$ arg medium.

\section{Selection of diploids}

The method used for selection of diploids was directly derived from that described by Ebersold $(1963,1967)$. Two different mutants are crossed under the usual conditions after which the mating mixture is plated on $\mathbf{M}$ medium and continuously incubated in the light. Only haploid wild-type recombinants and diploids in which complementation occurs are able to grow on this medium. Diploid colonies were easily distinguished from wildtype recombinants on the basis of the colony size after 5 days (under continuous light, diploid cells divide almost immediately after plating whereas 
the first meiotic division occurs at least 24 hours later). Large colonies were sampled, transferred on to $\mathrm{M}$ medium and kept for further study.

\section{Measuring cell volumes}

The algae were cultivated in liquid $\mathbf{M}$ medium. Samples were removed during exponential growth, diluted with 0.9 per cent. $\mathrm{NaCl}$ solution (filtered on Millipore) and counted in a Coulter model A electronic counter (diameter of the aperture: $100 \mu$ ). The size distribution of cells was determined after duplicate counts at different volume settings covering the entire range of cell volumes. The counter was previously calibrated with human red blood cells.

\section{Staining of nuclei and chromosomes}

For cytological observations, smears were prepared from fresh cultures on solid medium as described by Schaechter and DeLamater (1955). Cells were fixed for 5 minutes in alcohol-acetic acid $(3: 1)$ and hydrolysed for 6 minutes in $1 \mathrm{~N} \mathrm{HCl}$ at $60^{\circ} \mathrm{C}$.

Instead of the conventional method of staining with Azure A, we have adopted a new staining procedure which gave us good and quicker results. After hydrolysis, the preparations were rapidly washed in distilled water and then exposed to a solution of thionine (Merck) prepared according to M. Nicolle (quoted by Langeron, 1949): 1 volume saturated solution of thionine in 60 per cent. ethanol : 4 volumes 2 per cent. phenol in water.

The staining was allowed to proceed for 45 minutes. The preparations were washed in 0.1 per cent. acetic acid, quickly dehydrated in an alcoholxylol series and mounted in Canada balsam.

\section{Microscopy and microphotography}

A Zeiss microscope, Ultraphot II type, was used with $100 \times$ Neofluar and $100 \times$ phase contrast Neofluar (1.30 N.A.) oil immersion objectives. Highest contrast was obtained with a $537 \mathrm{~nm}$. interference filter.

Photographs were taken with Scientia Agfa Gevaert plates.

\section{Assays for enzyme activities}

Conditions of growth and preparation of cell-free extracts have been described previously (Sussenbach and Strijkert, 1969).

Argininosuccinate lyase (L-argininosuccinate arginine lyase, E.C. number 4.3.2.1.) was assayed after Hudock (1963) by measuring the appearance of arginine in crude extracts in the presence of argininosuccinate. The incubation mixture contained in a total volume of $2.5 \mathrm{ml}$.: $0.5 \mathrm{ml}$. extract,

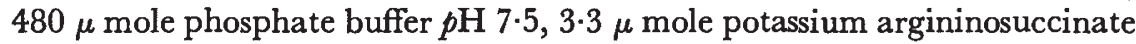
(prepared from barium salt by the method of Havir et al., 1965). The mixture was incubated for 1 hour at $37^{\circ} \mathrm{C}$. Reaction was stopped by immersing the tubes for 5 minutes in boiling water. An equal volume of 10 per cent. TCA was added and arginine was measured in the supernatant according to Van Pilsum (1956). The blanks were manipulated in the same way except that the substrate was added after incubation. As a rule, the activity of this enzyme was determined in extracts dialysed overnight against phosphate buffer at $4^{\circ} \mathrm{C}$.

Ornithine transcarbamylase (carbamoylphosphate: L-ornithine carbamoyltransferase, E.C. number 2.1.3.3.) was assayed according to Jones, Spector and Lipmann (1955). 
Protein was measured according to Lowry et al. (1951) with crystalline egg white lysozyme as a standard.

\section{Results}

\section{Genetical analysis}

Six arginine-requiring mutants deficient in argininosuccinate lyase were genetically analysed. These mutants were crossed in all possible combinations and the progeny was analysed by the zygote plating method (Levine and Ebersold, 1958). Moreover in certain crosses, more data have been gained from the random spore plating analysis.

Three groups of mutants have been clearly distinguished: Group I included arg-7-2, arg-7-3 and arg-7-4. No recombinant has ever been found in crosses involving these three mutants; they are located at the same site or separated from each other by less than 0.01 units. Group II included arg-7 and $\arg -7-5$ which are closely linked (distance between the two sites: 0.02 units). Groups I and II are 0.30 units apart (total number of zygotes analysed: 12,064; of spores analysed: 23,000). The group III mutant arg-7-1 did not give any $W T$ recombinant when crossed with mutants of the group I or of group II. It can therefore be considered as a multisite mutation involving a segment of chromosome that extends over the arg-7 region. This interpretation however remains provisional for this mutant shows a relatively high spontaneous reversion rate $\left(1 \cdot 10^{-6}\right.$ against less than $1 \cdot 10^{-7}$ in the five other strains).

The upper part of fig. 1 sums up the data of the genetical analysis.

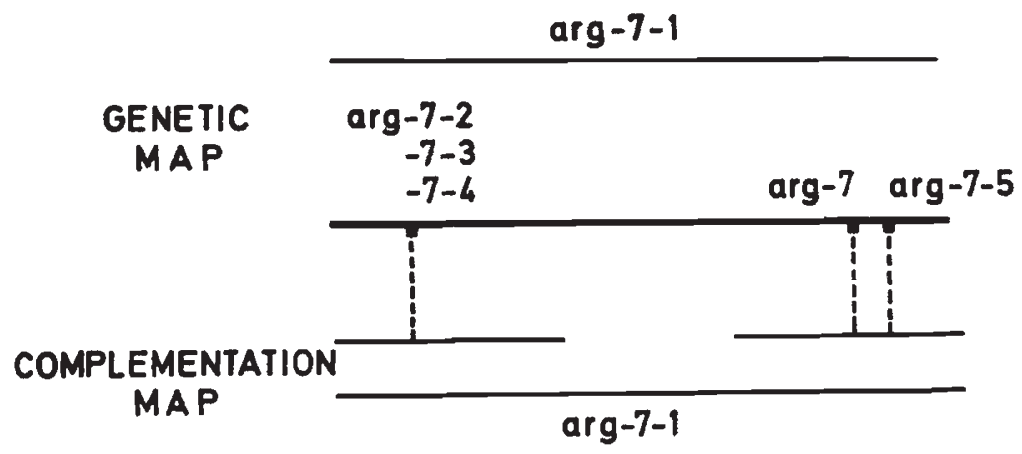

FIG. 1.-Genetic and complementation maps of the arg-7 region. The relative positions of arg- 7 and arg-7-5 are arbitrary.

It should be noted that in the recombination tests the size of the colonies developing from zygotes on $\mathbf{M}$ medium was often heterogeneous. This phenomenon has not been analysed.

The recombination frequencies were calculated by taking into account only the largest phenotypically wild-type colonies. These results were in good agreement with those obtained from the random spore plating analysis.

\section{Complementation tests}

Numerous examples are known in various organisms where two different mutants defective for the same enzyme complement in the diploid to restore some enzymatic activity. As the mutants of Chlamydomonas here described 
lack the same enzyme and are located at different sites, complementation may be expected to take place in this sytem. For testing this possibility, the method of Ebersold (1967) to obtain stable diploid clones has been applied. By this method, most of the zygotes undergo meiosis but some of them (4 per cent. in Ebersold's experiments) remain in the diploid phase and divide mitotically to form diploid colonies. Zygotes resulting from crosses between mutants located at different sites are expected to develop on $\mathbf{M}$ medium a few wild type haploid colonies as a result of recombination, and, if complementation is possible, numerous diploid colonies. Accordingly, when complementation occurs, the frequency of phenotypically $W T$ colonies obtained after Ebersold's method must be far higher than the frequency of haploid $W T$ recombinants.

The six mutants were crossed in all combinations and the zygotes were plated on $\mathrm{M}$ medium and incubated under continuous light (see Materials and methods). Crosses could be separated into two classes: one giving 5-20 per cent. $W T$ colonies, the other one $0-0 \cdot 1$ per cent. Table 1 indicates the combinations of mutants giving the high frequency of $W T$ colonies.

TABLE 1

Crosses giving high $(+)$ or low (-) frequencies of prototrophs in the complementation test

$\begin{array}{cccccc}\arg -7-3 & \text { arg-7-4 } & \text { arg-7 } & \text { arg-7-5 } & \text { arg-7-1 } & \\ - & - & + & + & - & \text { arg-7-2 } \\ & - & + & + & - & \text { arg-7-3 } \\ & & + & + & - & \text { arg-7-4 } \\ & & & - & - & \text { arg-7 } \\ & & & & & \end{array}$

It must be pointed out that a high percentage of $W T$ colonies was only obtained in crosses between mutants of groups I and II. Colonies regarded as diploids on the basis of their size were isolated for further study.

As a control, the method has been successfully used for selecting heterozygous diploid strains for the genes arg-1 and arg-7.

Groups I and II may be considered as complementation groups. A comparison of complementation and genetic maps is given in fig. 1 .

\section{Evidence for diploidy}

The mating-type of diploids is expected to be $m t^{-}$which is dominant over $m t^{+}$(Ebersold, 1967). This was indeed the rule for all presumptive diploids isolated in our experiments.

The distribution of cell volumes of $W T$ and various presumptive diploids in exponential growth phase has been studied using the electronic Coulter counter. Comparison of cell volume distribution for $W T$ and for a presumptive diploid is presented in fig. 2. The $W T$ cell population is rather homogeneous and is included within the limits 25-200 $\mu^{3}$. On the contrary, the size of the presumptive diploid cells is very heterogenous: the distribution curve is much more spread and the cell volumes range from 50 to $600 \mu^{3}$; the same heterogeneity in cell size was found in all presumptive diploids so far analysed. The distribution curves (two experiments for each strain) were used to determine the mean cell volumes (table 2): in all cases it was found that the mean cell volumes of presumptive diploids are 2 to 3.5 times higher than the $W T$ cell volume.

That the strains quoted in table 2 are diploids was also confirmed by the 
results of genetical analysis. When these strains were crossed with $W T(t)$, most of the spores issuing from the zygotes were lethal (more than 80 per cent. of the cells failed to give rise to vegetative colonies as pointed out by Ebersold, 1967) but among the surviving progeny, arginine-deficient segregants were always recovered.

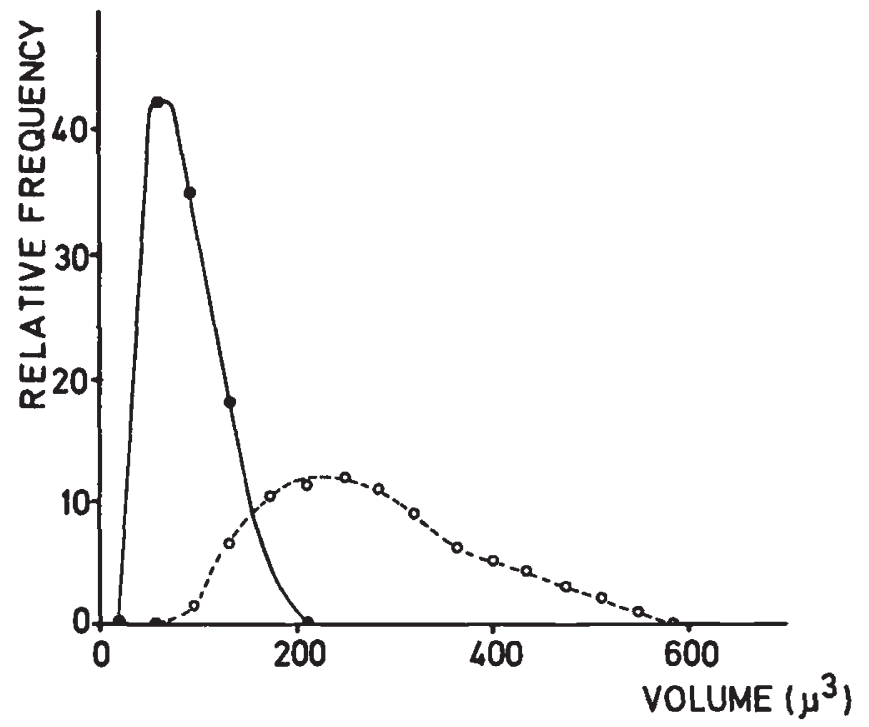

FIg. 2.-Distribution curves of cell volumes obtained for the haploid $W T$ strain (solid line) and a presumptive diploid strain obtained from the cross $\arg -7-5 \times$ arg-7-3 (broken line).

A detailed cytological study of the strain 75-73-3 has been performed to estimate the chromosome number. It is quite evident from plate I (1-2) that in addition to differences in the cell sizes, differences do also exist in nuclear sizes between $W T$ and 75-73-3. In the latter, the nuclei are larger

TABle 2

Cell volumes of WT and various presumptive diploids

$\begin{array}{lcc}\text { Cross } & \text { Isolate } & \begin{array}{c}\text { Cell volume } \\ \left(\mu^{3}\right)\end{array} \\ \text { arg- } 1 \times \text { arg-7 } & & 223 \\ \text { arg-7 } \times \text { arg-7-2 } & 1-7-1 & 171 \\ & 1-7-2 & 142 \\ \text { arg-7-5 } \text { arg-7-3 } & 7-72-1 & 152 \\ & 7-72-2 & 209 \\ & 75-73-2 & 200 \\ \text { Haploid } W T \text { (control) } & 75-73-3 & 247 \\ & 75-73-4 & 71\end{array}$

but often less densely stained than in the $W T$; this character has been verified in many preparations of this strain and also in other presumptive diploids.

The original staining method used in the present work gave good pictures of chromosomes in WT and 75-73-3 strains. Photographs 3 and 4 in plate I clearly show 16 chromosomes in squashed metaphases of WT cells; this chromosome number was found in other well spread metaphases. We were 
fortunate to observe an early metaphase stage in which differences in morphology and size of Chlamydomonas chromosomes (plate I, 3) are clearly visible. This figure of 16 chromosomes is in good agreement with the data of Schaechter and DeLamater (1955) and Wetherell and Krauss (1956) and with the occurrence of 16 well defined linkage groups in Chlamydomonas reinhardi (Hastings et al., 1965).

It is rather difficult to reconcile these data with those of Buffaloe (1958) and Levine and Folsome (1959) who found $n=8$ for Chlamydomonas reinhardi.

Exact chromosome counts in 75-73-3 were difficult owing to the large number of chromosomes and the lack of flatness of the metaphases. Plate I (5-9) shows a typical metaphase plate photographed at 5 focal levels: an interpretative drawing constructed from these five pictures leads to a count of 30 chromosomes (plate I, 10). Although only a few suitable metaphases were found, the number of 26-32 chromosomes can be assessed for this strain. Hence, this caryological study strongly suggests that $75-73-3$ is a true diploid.

\section{Enzymatic studies}

The activity of argininosuccinate lyase (ASL) has been measured in various diploid strains and in the haploid $W T$ strain. As it was previously demonstrated that in $W T$ this enzyme was repressible by $\mathrm{NH}_{4}^{+}$ions (Strijkert et al., 1971), the activities of ASL were determined in cells grown in media containing varying concentrations of $\mathrm{NH}_{4} \mathrm{Cl}$ (20 to $400 \mathrm{mg}$./1.).

Detailed results for three typical diploid strains resulting from the crosses $\arg -1 \times$ arg- $7(1-7-1)$, arg-7-5 $\times$ arg-7-3(75-73-3) and arg-7 $\times$ arg-7-2(7-72-1) are given in table 3 . As a control, the activities of another enzyme of the arginine biosynthesis (ornithine transcarbamylase: OTC) were measured in cells grown in the same conditions.

TABLE 3

Specific activities of argininosuccinate lyase and ornithine transcarbamylase in extracts of WT and diploid strains grown in mineral media containing various quantities of $\mathrm{NH}_{4} \mathrm{Cl}$. Each value was determined from a minimum of 3 independent experiments

S.A. of argininosuccinate lyase ( $\mu$ mole arginine $/ \mathrm{mg}$. protein $/ \mathrm{h} ., 37^{\circ} \mathrm{C}$.)

\begin{tabular}{|c|c|c|c|c|}
\hline $\begin{array}{l}\mathrm{NH}_{4} \mathrm{Cl} \\
\text { (mg./l.) }\end{array}$ & $W T$ & $\begin{array}{c}\arg -1 \times \\
\arg -7 \\
1-7-1\end{array}$ & $\begin{array}{c}\arg -7-5 \times \\
\arg -7-3 \\
75-73-3\end{array}$ & $\begin{array}{c}\arg -7 x \\
\arg -7-2 \\
7-72-1\end{array}$ \\
\hline $\begin{array}{r}20 \\
40 \\
400\end{array}$ & $\begin{array}{l}3.38 \\
2.59 \\
0.90\end{array}$ & $\begin{array}{l}1.83 \\
1.17 \\
0.37\end{array}$ & $\begin{array}{l}0.97 \\
0.85 \\
0.12\end{array}$ & $\begin{array}{l}0.70 \\
0.48 \\
0.12\end{array}$ \\
\hline $20 \mathrm{mg} / \mathrm{l}$. & 3.8 & $5 \cdot 2$ & $8 \cdot 1$ & $5 \cdot 8$ \\
\hline
\end{tabular}

S.A. of ornithine transcarbamylase ( $\mu$ mole citrulline/mg. protein $/ \mathrm{h} ., 37^{\circ} \mathrm{C}$.)

$\begin{array}{cccc} & \begin{array}{c}\text { arg- } 1 \times \\ \text { arg-7 }\end{array} & \begin{array}{c}\text { arg-7-5 } \\ \text { arg-7-3 }\end{array} & \begin{array}{c}\text { arg-7 } \\ \text { arg-7-2 }\end{array} \\ W T & 1-7-1 & 75-73-3 & 7-72 .-1 \\ 50.5 & 52.8 & 78.3 & 50.2 \\ 22.7 & - & 37.3 & - \\ 5.7 & 3.4 & 5.1 & 4.1 \\ 8.9 & 15.5 & 15.4 & 12.2\end{array}$

It can be seen that the activity of ASL is lower in diploids than in $W T$. This result has been confirmed for other diploids from the crosses mentioned here above and from the cross arg-7-5 x arg-7-2. The highest ASL activity (39 per cent. of $W T$ activity) was found in the strain 75-73-2 cultivated on $40 \mathrm{~N}$ medium. Among all isolated diploids, the highest activities of ASL were always found in heterozygous arg-1/arg-7 strains. On the other hand no major difference in OTC activity was found between $W T$ and diploids.

It must be pointed out that, when the cells are grown on medium poor in $\mathrm{NH}_{4}^{+}$, i.e. when the ammonium pool in the cells is lowered (Strijkert et al. 
1972), a higher activity of both enzymes is found in diploids as in WT: this confirms our previous results where it was shown that in Chlamydomonas numerous enzymes of arginine metabolism were repressible by ammonium (Strijkert et al., loc. cit.). The effect of $\mathrm{NH}_{4}^{+}$seems even stronger in diploids than in $W T$ : the ratios of activities of ASL and OTG in cells grown respectively on $20 \mathrm{~N}$ and $400 \mathrm{~N}$ media are higher in diploids. It is difficult to conclude whether the differences between the ratios are highly significant since the accuracy of the assays decreases at low enzyme activities. However it may be, the factors of enzyme regulation have to be taken into account for comparing enzymatic activities in $W T$ and complementing diploids. For example, the activity of ASL in 75-73-3 varies from 29 to 13 per cent. of the specific activity of the $W T$ ASL enzyme when cells are grown on $20 \mathrm{~N}$ and $400 \mathrm{~N}$ media, respectively. We may notice that the lowest ASL enzyme activity in this strain (S.A. $=0 \cdot 12$ ) grown on $400 \mathrm{~N}$ medium is still sufficient to allow normal growth rate.

\section{Heat sensitivity and Michaelis constants of the enzymes produced by complementing mutants}

It has been shown in many systems that the enzymes formed by interallelic complementation are hybrid molecules (dimers or multimers) which may differ in certain properties from the standard enzyme produced by the $W T$ strain, especially in their sensitivity to heat.

The crude extracts of different diploids were pre-incubated at $55^{\circ} \mathrm{C}$. for 30 minutes after which the ASL activities were measured. All the enzymes formed by complementation were found to be more heat labile than the standard $W T$ enzyme (table 4 ). The heat sensitivity was dependent on the kind of mutants associated in the diploid, whereas little variability was observed between different diploid strains obtained from the same cross.

TABLE 4

Heat sensitivity of argininosuccinate lyase from WT and diploids

\begin{tabular}{|c|c|c|}
\hline Strain & Origin & $\begin{array}{c}\% \text { of initial enzyme } \\
\text { activity remaining } \\
\text { after } 30 \mathrm{~min} . \text { at } \\
55^{\circ} \mathrm{C} \text {. }\end{array}$ \\
\hline$W T$ & - & 78 \\
\hline $1-7-1$ & $\arg -1 \times \arg -7$ & 59 \\
\hline $1-7-2$ & $\arg -1 \times \arg -7$ & 63 \\
\hline $75-73-2$ & $\arg -7-5 \times$ arg $-7-3$ & 12 \\
\hline $75-73-3$ & $\arg -7-5 \times$ arg $-7-3$ & 8 \\
\hline $75-73-4$ & $\arg -7-5 \times$ arg $-7-3$ & $<5$ \\
\hline $7-72-1$ & $\arg -7 \times \arg -7-2$ & 55 \\
\hline $7-72-2$ & $\arg -7 \times \arg -7-2$ & 43 \\
\hline
\end{tabular}

The rates of heat inactivation of ASL from $W T, 1-7-1$ and 75-73-3 strains are plotted in fig. 3. For both diploid strains, the decay of the enzyme activity was exponential which suggests that only one type of enzyme molecule is formed. The rate of inactivation of the enzyme 1-7-1 was slightly greater than for the $W T$ enzyme, as found in several independent experiments and for the enzyme of another strain (1-7-2) obtained from the same cross arg-1 $\times$ arg-7. Such a difference is difficult to explain since, in this particular case, one expects that the standard $W T$ enzyme (synthesised under the control of the arg-1 genome) should be present. However, small 


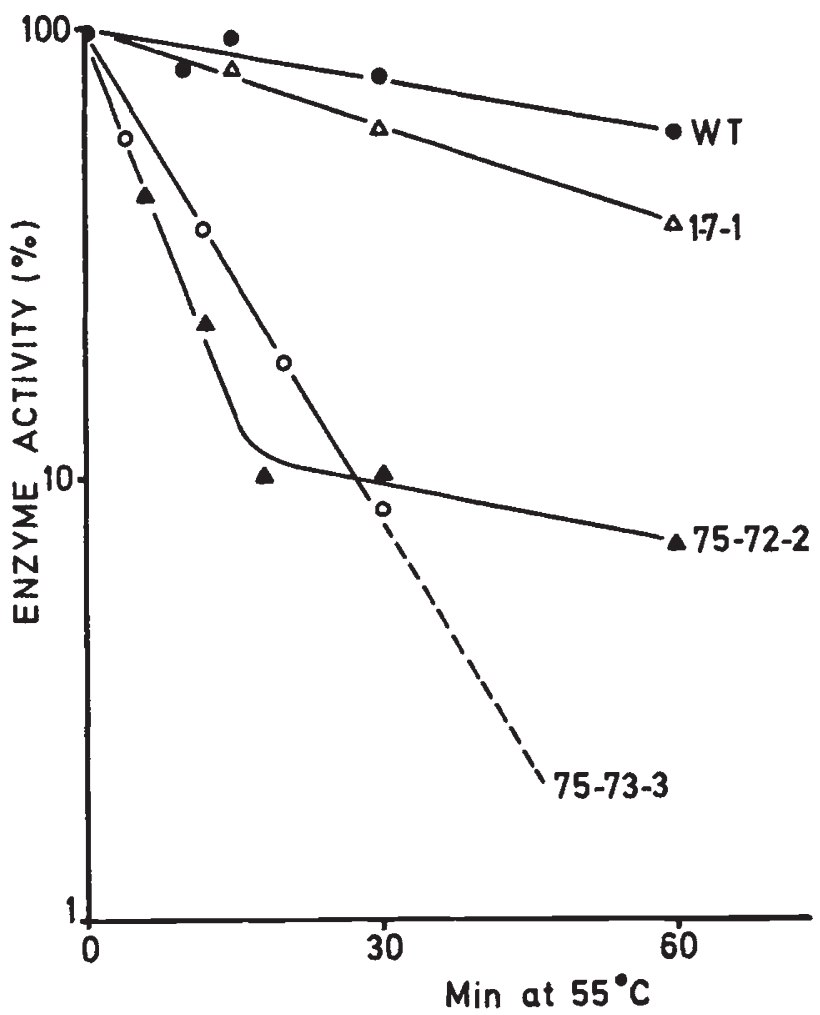

Fic. 3.-Heat inactivation curves of the enzymes produced by $W T, 1-7-1,75-73-3$ and 75-72-2. The values are calculated as per cent. of the initial activity of each strain. In 75-73-3, no activity was detectable after 60 minutes at $55^{\circ} \mathrm{C}$.

differences can easily occur especially when the protein concentration is not the same in all cases (Fincham, personal communication).

A more complex example of thermal inactivation has been found in a strain obtained from the cross arg-7-5 $\times$ arg-7-2 (75-72-2) (fig. 3). This strain seems to produce two enzymically active ASL components. The initial slope of the inactivation curve can be attributed to a highly labile hybrid enzyme and the final slope to another enzyme having approximately the same stability as the enzyme produced by $W T$ (the final slope being parallel to the slope for the WT enzyme).

The reaction velocities of ASL from $W T$ and from two diploids (75-73-3 and 7-72-1) as functions of argininosuccinate concentrations were determined (fig. 4). The results indicate that although alterations are present in ASL from the two diploids (these enzymes are both more heat labile than the WT enzyme), they are not reflected in significantly altered affinity for the substrate (the calculated $K m$ 's for $W T$, 75-73-3 and 7-72-1 enzymes are respectively $1.39 \times 10^{-4} \mathrm{M}, 1.66 \times 10^{-4} \mathrm{M}$ and $1.75 \times 10^{-4} \mathrm{M}$ ). This might mean that in enzymes formed by complementation at least one active centre has normal affinity for substrate.

\section{Discussion}

The existence of eight mutants lacking the same enzyme argininosuccinate lyase in Chlamydomonas reinhardi makes possible a preliminary study of the 


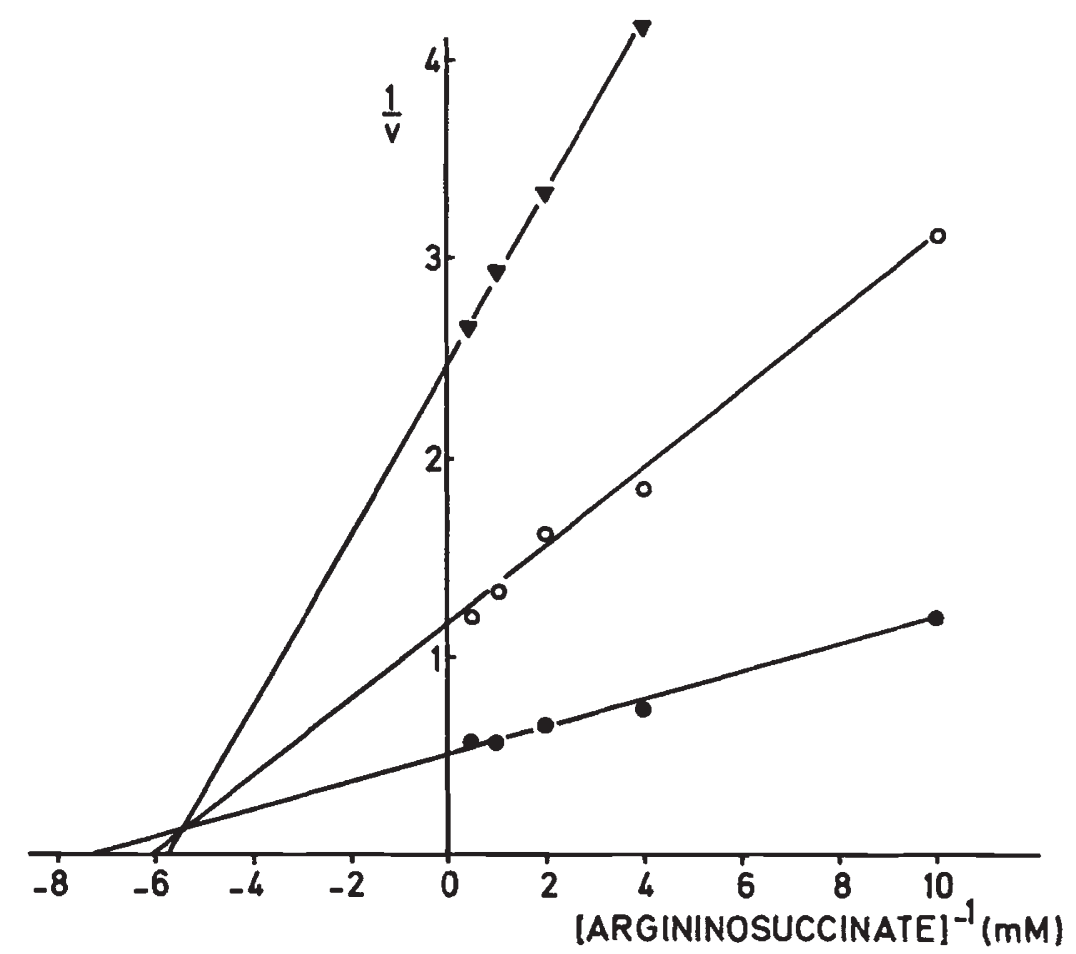

FIG. 4.-Lineweaver-Burk plots for the calculation of the Michaelis constants for argininosuccinate in enzymic crude extracts of $W T(0-0), 75-73-3(0-0)$ and 7-72-1

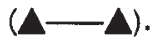

$\mathrm{v}$ : $\mu$ mole arginine formed in $1 \mathrm{~h}$. $\left(37^{\circ} \mathrm{C}\right.$.) per $\mathrm{mg}$. protein.

fine structure of a gene and of gene-enzyme relationships in this organism. In the present work, six mutants were genetically investigated and it was demonstrated that five of them fell into two distinct recombination groups 0.30 unit apart. The existence of other mutant sites within this region must be presumed; a more detailed fine structure map of arg-7 must wait until a larger number of mutants are available. Nevertheless, the occurrence of mutants separated on the genetic map led us to investigate whether complementation took place in this system.

By crossing mutants belonging to the different groups, presumptive diploid strains, phenotypically wild-type, were recovered. It was shown that these strains were larger in cell size than haploid $W T$ and, when crossed to wild, gave rise to arginine-deficient segregants.

For one strain (75-73-3), it was moreover found that nucleus volumes were higher than in $W T$ cells and chromosome number was approximately twice the haploid number (16). This strain is most probably a true diploid. This finding does not exclude the possibility that other strains are hyperhaploids having at least the chromosome carrying the arg-7 gene duplicated.

The activity of argininosuccinate lyase (ASL) in all arg-7 diploids was lower than in WT, ranging from 13 to 39 per cent. according to the nature of the cross, the strain and the quantity of $\mathrm{NH}_{4}^{+}$present in the culture medium. The highest activity ( 39 per cent. of $W T$ ) was found for a strain obtained from the cross arg-7-5 $\times$ arg-7-3 (75-73-2) cultivated on a medium poor in 
ammonium $(40 \mathrm{~N})$. This level of enzyme activity is relatively high in comparison with what has been found in other systems displaying interallelic complementation: glutamate dehydrogenase (Fincham, 1959) and tryptophan synthetase (Suyama and Bonner, 1964) in Neurospora, threonine dehydratase in $S$. cerevisiae (Zimmermann and Gundelach, 1969), but it is still far lower than the 67 per cent. of wild-type alkaline phosphatase activity found in one pair of mutant $p$ alleles in Escherichia coli (Garen and Garen, 1963).

Among the six mutants analysed in the present work, five were able to complement in diploids. As discussed by Fincham (1966), complementing mutants have to present particular qualities: "the ability to make a protein sufficiently abnormal to give a mutant phenotype but not so abnormal as to be incapable of correction in a hybrid multimer. These requirements may be met by only a small minority of mutants in some gene protein systems." It is highly surprising that five of the six mutants here studied, all of them fully auxotrophic, showed complementation.

More important are the preliminary results we obtained on the properties of the ASL enzymes produced by $W T$ and diploids. It was shown that in all diploids, the heat inactivation curves for ASL were different from the corresponding curve obtained for the standard WT enzyme. This indicates that ASL formed by complementation differs from the WT enzyme, which is in agreement with many data of the literature for a number of hybrid enzymes formed by interallelic complementation (Partridge, 1960; Fincham and Coddington, 1963; Gross and Webster, 1963; Garen and Garen, 1963; Perrin, 1963; Suyama and Bonner, 1964).

Some more information may be drawn from the inactivation curves given in fig. 3 .

1. In 75-73-3, a single enzyme different from the $W T$ protein was found and the fact that apparently no $W T$ enzyme was produced by this strain favours the hypothesis according to which the $\arg -7$ gene corresponds to one cistron (the fact that we did not find any significant difference in Michaelis constants for WT, 75-73-3 and 7-72-1 (fig. 4) is not in contradiction with this hypothesis).

To support this proposal, one should demonstrate for example that there exist more than two complementation groups. This could be shown only when sufficient number of mutants are available since the number of segments on a complementation map has a general tendency to increase with the number of mutants tested (Fincham, 1966). To interpret the data one obviously needs to know the size and composition of the subunits constituting Chlamydomonas ASL. At the present time, only preliminary data have been published on the ASL of beef liver; they indicate that this enzyme is formed of several subunits of still unknown number and composition (Havir et al., 1965).

2. If one assumes that the $\arg -7$ gene corresponds to one cistron and that the enzyme is constituted of identical subunits, one can also speculate about the number of subunits on the basis of the results obtained for 75-72-2. The kinetics of the heat inactivation reaction for this strain is diphasic, indicating the presence of two different enzyme species. One could then believe that the ASL present in Chlamydomonas is 
composed of more than two identical subunits (if the protein was formed of only two identical subunits one might expect to find a single species of enzyme (see Fincham and Coddington, 1963)).

3. Inactivation curves also allow one to distinguish mutants which belong to the same complementation group. The mutants $\arg -7$ and $\arg -7-5$, located at closely linked but separable sites, do not complement each other but, when associated with arg-7-2, they form active enzymes different in their heat sensitivity.

It is interesting to note that $\arg -7-2$ and $\arg -7-3$, although not separable by recombination or by complementation, complement with arg-7-5 to produce enzymes once more distinguishable on the basis of heat inactivation. This means that arg-7-2 and arg-7-3 do not carry the same mutational alteration and must be located at different sites too closely linked to be resolved by our present analysis.

\section{SUmmary}

1. Six mutants of the green alga Chlamydomonas reinhardi all lacking the same enzyme argininosuccinate lyase (ASL) have been genetically analysed. All mutants were shown to be clustered within a short segment (the arg-7 locus) in linkage group $I$.

2. Two sets of mutants were found which complemented each other in diploids. The phenotypically $W T$ diploids were distinguished from the $W T$ haploid strain according to various criteria: mating-type, cell size, chromosome number, segregation of arg- mutants after crossing with $W T$.

3. The activity of ASL and its regulation by ammonium have been studied in complementing diploids and in the WT strain: the enzyme activity in diploids ranged from 13 to 39 per cent. of the $W T$ enzyme activity.

4. In two diploids, the enzyme was more heat sensitive than the $W T$ enzyme but no difference in the Michaelis constants was found.

5. The results are discussed in relation to the definition of the arg-7 locus and to the number of subunits making up the ASL enzyme.

Acknowledgments.-The authors wish to thank Professor J. R. S. Fincham, Department of Genetics, University of Leeds, for his written suggestions and valuable criticism of the manuscript. The technical assistance of Mrs T. A. M. de Natris-Verkleij is gratefully acknowledged.

\section{REFERENCES}

BUFfaLOE, N. D. 1958. A comparative cytological study of four species of Chlamydomonas. Bull. Torrey Club, 85, 157-178.

EBERSOLD, w. T. 1956. Crossing-over in Chlamydomonas reinhardi. Amer. F. Bot., 43, 408-410. EBERSOLD, w. T. 1963. Heterozygous diploid strains of Chlamydomonas reinhardi. Genetics, 48, 888 (abstract).

EBERsoLd, w. T. 1967. Chlamydomonas reinhardi: heterozygous diploid strains. Science, 157, 447-449.

FINGHAM, J. R. s. 1959. On the nature of the glutamic dehydrogenase produced by interallelic complementation at the am locus of Neurospora crassa. F. Gen. Microbiol., 21, 600611.

FinCHAM, J. R. S. 1966. Genetic complementation. Benjamin, New York.

FINCHAM, J. R. S., AND CODDINGTON, A. 1963. The mechanism of complementation between am mutants of Neurospora crassa. Cold Spring Harbor Symp. quant. Biol., 28, 517-527. 

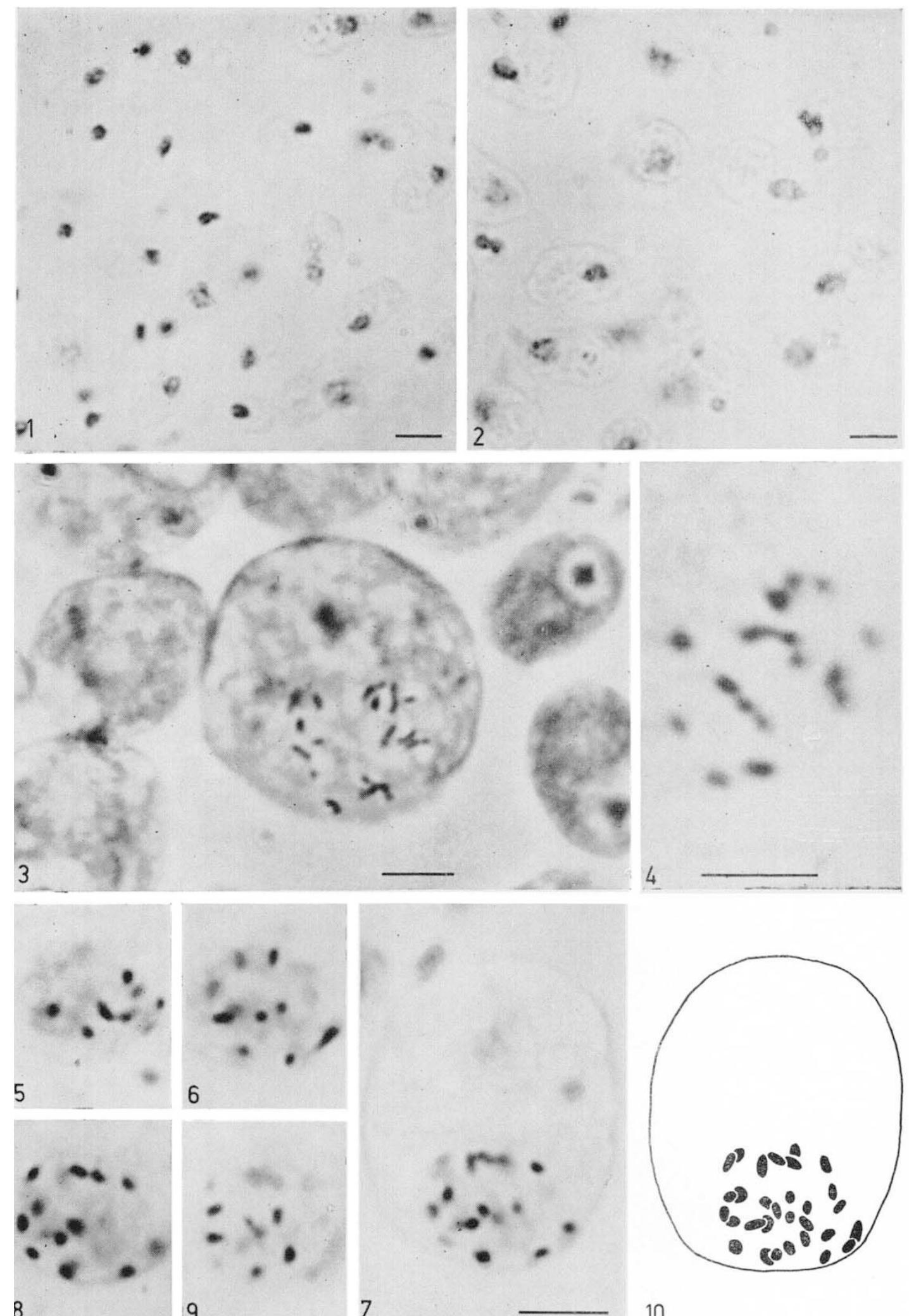

8

9
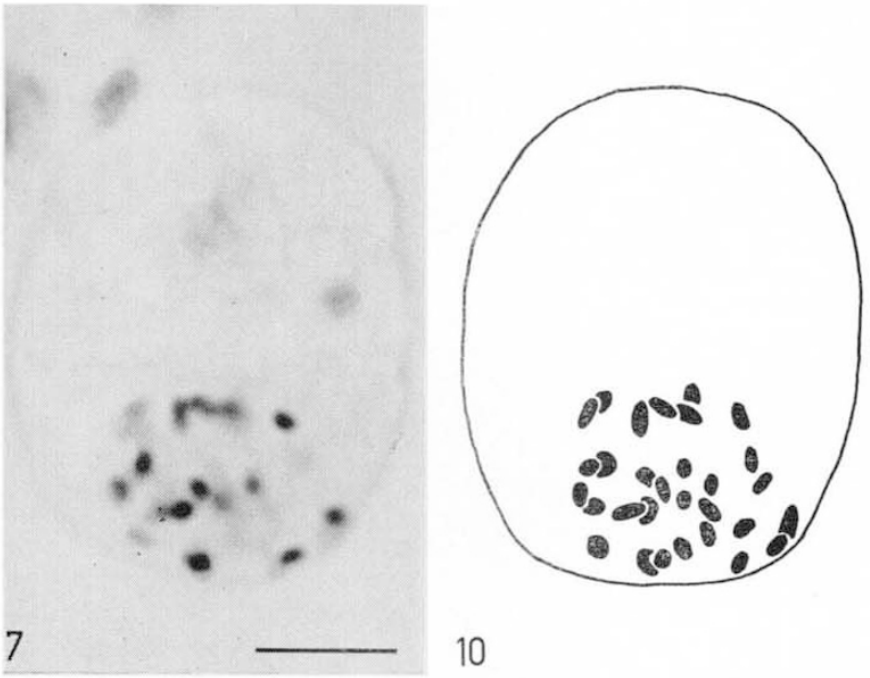

PLATE I.-Microphotographs of vegetative cells of $W T$ and of the diploid strain 75-73-3.

Thionine stain. The lines indicate $3 \mu$.

1-2: Cells with interphase nuclei of $W T$ and 75-73-3, respectively.

3: Early metaphase in a $W T$ cell showing 16 chromosomes (phase contrast)

4: Another metaphase plate in $W T$ at high magnification ( 16 chromosomes visible).

5-9: Photographs of a metaphase plate of 75-73-3 at five different focal levels.

10: Interpretative drawing of the cell presented in 5-9, showing 30 chromosomes. 
GAREN, A., AND GAREN, s. 1963. Complementation in vivo between structural mutants of alkaline phosphatase from E. coli. F. Mol. Biol., 7, 13-22.

GILlHAM, N. W. 1965. Induction of chromosomal and non-chromosomal mutations in Chlamydomonas reinhardi with N-methyl-N'-nitro-N-nitrosoguanidine. Genetics, 52, 529537.

GROSS, S. R., AND WEBSTER, R. E. 1963. Some aspects of interallelic complementation involving leucine biosynthetic enzymes of Neurospora. Cold Spring Harbor Symp. quant. Biol., 28, 543-547.

hastings, P. J., LEVINe, E. E., COSBEY, E., hUdOCK, M. O., GillhaM, N. W., SURzYCKI, s. J., LOPPES, R., AND LEVINE, R. P. 1965. The linkage groups of Chlamydomonas reinhardi., Microbial Genetics Bull., 23, 17-19.

HAVIR, E. A., TAMIR, H., RATNER, s., AND WARNER, R. c. 1965. Biosynthesis of Urea. XI. Preparation and properties of crystalline argininosuccinase. 7. Biol. Chem., 240, 3079. 3088.

HUDOCK, G. A. 1963. Repression of arginosuccinase in Chlamydomonas reinhardi. Biochem. Biophys. Res. Comm., 10, 133-138.

JONES, M. E., SPECTOR, L., AND LIPMANN, F. 1955. Carbamyl phosphate, the carbamyl donor in enzymatic citrulline synthesis. F. Am. Chem. Soc., 77, 819-820.

langeron, M. 1949. Précis de microscopie. Masson et Cie, Paris.

LEVINE, R. P., AND EBERSOld, w. T. 1958. Gene recombination in Chlamydomonas reinhardi. Cold Spring Harbor Symp. quant. Biol., 23, 101-109.

LEVINE, R. P., AND FOLSOME, C. E. 1959. The nuclear cycle in Chlamydomonas reinhardi. $Z$. Vererbungsl., 90, 215-222.

LOPPES, R. 1966. Damage induced by methyl methanesulfonate (MMS) in Chlamydomonas reinhardi. Z. Vererbungsl., 98, 193-202.

LOPPES, R. 1969. A new class of arginine-requiring mutants in Chlamydomonas reinhardi. Molec. Gen. Genetics, 104, 172-177.

LOPPES, R. 1970. Selection of arginine-requiring mutants in Chlamydomonas reinhardi after treatment with three mutagens. Experientia (Basel), 26, 660-661.

LOWRy, O. H., ROSEBrough, N. J., FARR, A. L., AND RANDALl, R. J. 1951. Protein measurement with the Folin phenol reagent. F. Biol. Chem., 193, 265-275.

PARTRIDGe, c. w. H. 1960 . Altered properties of the enzyme, adenylosuccinase, produced by interallelic complementation at the ad-4 locus in Neurospora crassa. Biochem. Biophys. Res. Comm., 3, 613-619.

PERRIN, D. 1963. Complementation between products of the $\beta$-galactosidase structural gene of Escherichia coli. Cold Spring Harbor Symp. quant. Biol., 28, 529-532.

SChaEchter, M., and delamater, E. D. 1955. Mitosis of Chlamydomonas. Amer. J. Bot., 42, 417-422.

STARLING, D. 1969. Complementation tests on closely linked flagellar genes in Chlamydomonas reinhardi. Genet. Res. (Camb.), 14, 343-347.

STRIJKERT, P. J., AND SUSSENBACH, J. s. 1969. Arginine metabolism in Chlamydomonas reinhardi. Evidence for a specific regulatory mechanism of the biosynthesis. Europ. 7. Biochem., 8, 408-412.

STRIJKERT, P. J., LOPPES, R., AND MATAGNE, R. 1971. Arginine metabolism in Chlamydomonas reinhardi-Enzyme repression by ammonium. Biochem. Biophys. Res. Comm. (in the press). SUSSENBACH, J. S., AND STRIJKERT, P. J. 1969. Arginine metabolism in Chlamydomonas reinhardi. On the regulation of the arginine biosynthesis. Europ. 7. Biochem., 8, 403-407.

SUYAMA, Y., AND BONNER, D. M. 1964. Complementation between tryptophan synthesis mutants of Neurospora crassa. Biochim. Biophys. Acta, 81, 565-575.

VAN PILSUM, J. F., MARTIN, R. P., KITO, E., AND HESs, J. 1956. Determination of creatine, creatinine, arginine, guanidoacetic acid, guanidine and methylguanidine in biological fluids. J. Biol. Chem., 222, 225-236.

WETHERELL, D. F., AND KRAUSS, R. W. 1956. Colchicine-induced polyploidy in Chlamydomonas. Science, 124, 25-26.

ZIMMERMANN, F. K., AND GUNDELACH, E. 1969. Intragenic complementation, hybrid enzyme formation and dominance in diploid cells of Saccharomyces cerevisiae. Molec. Gen. Genetics, $103,348-362$. 